\title{
"Supporting Information" \\ Adsorptive Removal of Unsaturated Fatty Acids using Ion Exchange Resins
}

By

Manisha A. Khedkar', Satchidanand R. Satpute², Sandip B. Bankar ${ }^{3}$, Prakash V. Chavan*1 pvcuict@gmail.com

1: Department of Chemical Engineering, Bharati Vidyapeeth (Deemed to be University), College of Engineering, Maharashtra, Pune- 411 043, INDIA

2: Department of Chemical Engineering, Vishwakarma Institute of Technology, Maharashtra, Pune- 411 037, INDIA

3: Department of Bioproducts and Biosystems, Aalto University School of Chemical Engineering, P. O. Box 16100, FI- 00076 Aalto, FINLAND

*Author to whom all the correspondence should be addressed

Phone: +91-20-24107310, Fax: +91-20-24372998

Email: pvchavan@bvucoep.edu.in,pvcuict@gmail.com 
Table S1: Separation techniques for fatty acid

\begin{tabular}{|c|c|c|c|}
\hline S.N. & $\begin{array}{l}\text { Separation } \\
\text { method }\end{array}$ & Summary & Reference \\
\hline 1 & Distillation & $\begin{array}{l}\text { Free fatty acid (FFA) containing } 57.8 \%\left(\mathrm{w} . \mathrm{w}^{-1}\right) \text { oleic } \\
\text { acid was subjected to vacuum distillation at } 10^{-6} \text { bar } \\
\text { pressure. Oleic acid was found to be } 2.3 \%\left(\mathrm{w} . \mathrm{w}^{-1}\right) \text { in the } \\
\text { residue at the end of operation. Although appreciable } \\
\text { separation efficiency ( } 96 \%) \text { was achieved, the } \\
\text { requirement of high vacuum demands high initial cost of } \\
\text { equipment. Further, vacuum distillation was energy } \\
\text { intensive owing to high operating cost to maintain the } \\
\text { vacuum. }\end{array}$ & [9] \\
\hline 2 & $\begin{array}{l}\text { Chemical method } \\
\text { by esterification }\end{array}$ & $\begin{array}{l}\text { Mixed crude oil containing } 12 \%\left(\mathrm{w} . \mathrm{w}^{-1}\right) \text { FFA was } \\
\text { esterified with methanol in the presence of sulphuric } \\
\text { acid as a catalyst at } 60{ }^{0} \mathrm{C} \text { for } 12 \mathrm{~h} \text {. Although } 80 \% \text { FFA } \\
\text { was converted in methyl ester, the reaction was time and } \\
\text { energy demanding. }\end{array}$ & [12] \\
\hline 3 & Crystallization & $\begin{array}{l}\text { Crude palm oil containing } 3 \%\left(\mathrm{w} . \mathrm{w}^{-1}\right) \text { FFA was } \\
\text { subjected to crystallization with an optimized cooling } \\
\text { rate of } 17{ }^{0} \mathrm{C} \cdot \mathrm{h}^{-1} \text { from } 70{ }^{0} \mathrm{C} \text { to } 25{ }^{0} \mathrm{C} \text {. The residual FFA } \\
\text { was observed to be } 0.5 \%\left(\mathrm{w} . \mathrm{w}^{-1}\right) \text { after } 2.94 \mathrm{~h} \text {. The } \\
\text { cooling rate was observed to be an important operating } \\
\text { parameter for nucleation and crystal growth to achieve }\end{array}$ & [13] \\
\hline
\end{tabular}




\begin{tabular}{|c|c|c|}
\hline & & desired separation efficiency of FFA. \\
\hline 4 & Supercritical & $\begin{array}{l}\text { The rice bran oil containing } 10 \%\left(\mathrm{w} . \mathrm{w}^{-1}\right) \mathrm{FFA} \text { was } \\
\text { subjected } \mathrm{CO}_{2} \text { super critical extraction at } 250 \text { bar } \\
\text { pressure until FFA content in oil reduced to } 0.13 \% \\
\left(\mathrm{w} \cdot \mathrm{w}^{-1}\right) \text {. Although } \mathrm{CO}_{2} \text { super critical extraction of FFA } \\
\text { shows good separation efficiency, requirement of high } \\
\text { pressure for a predetermined separation efficiency of } \\
\text { FFA leads to high initial cost of equipment and } \\
\text { operating cost. }\end{array}$ \\
\hline 5 & $\begin{array}{l}\text { Membrane } \\
\text { separation }\end{array}$ & $\begin{array}{l}\text { FFA mixture containing } 50 \%\left(\mathrm{w} . \mathrm{w}^{-1}\right) \text { oleic acid with } \\
\text { tripropylamine and elaidic acid was subjected to } \\
\text { membrane separation using polydicyclopentadiene } \\
\text { (PDCPD) membrane and dichloromethane and methanol } \\
\text { as a diluents. The operation was, however, time } \\
\text { intensive }(72 \mathrm{~h}) \text { with merely separation efficiency of } 17 \\
\% \text { for oleic acid. }\end{array}$ \\
\hline
\end{tabular}

